JEL: H24, H26, H31

DOI: 10.5937 lindustrija43-6963

UDC: $336.226 .1(497.11) \quad 336.228 .34$

Original Scientific Paper

\title{
Tax Design-Tax Evasion Relationship in Serbia: New Empirical Approach to Standard Theoretical Model
}

\author{
Article history: \\ Received: 15 October 2014 \\ Sent for revision: 13 November 2014 \\ Received in revised form: 15 January 2015 \\ Accepted: 16 January 2015 \\ Available online: 1 April 2015
}

\begin{abstract}
This paper provides evidence on the impact of the change in income tax rates and the degree of its progressivity on the scale of labour taxes evasion in Serbia, using the tax-benefit microsimulation model and econometric methods, on 2007 Living Standard Measurement Survey data. The empirical analysis is based on novel assumption that individual's tax evasion decision depends on a change in disposable income, which is captured by the variation in their Effective Marginal Tax Rates (EMTR), rather than on a change in after-tax income. The results suggest that the elasticity of tax evasion to EMTR equals -0.3, confirming the Yitzhaki's theory, while the propensity to evade is decreasing in the level of wages and increasing in the level of self-employment income. The results also show that introduction of revenue-neutral, progressive taxation of labour income would lead to increase in labour tax evasion by 1 percentage point.
\end{abstract}

Key words: Tax evasion; Tax reform; Dual income tax; Effective marginal tax rate

\section{Veza između dizajna i utaje poreza u Srbiji: novi empirijski pristup standardnom teorijskom modelu}

Apstrakt: U ovom radu se istražuje uticaj promene stope poreza na dohodak građana $i$ intenziteta progresivnosti na nivo utaje poreza na dohodak od rada u Srbiji, koristeći mikrosimulacioni model poreskih i socijalnih politika i metode ekonometrijske analize, na podacima iz Ankete o životnom standardu iz 2007.godine. U radu se po prvi put, koristeći koncept efektivnih graničnih

\footnotetext{
${ }^{1}$ University of Belgrade, Faculty of Economics, randjelovic@ekof.bg.ac.rs 
Ranđelović S.: Tax Design-Tax Evasion Relationship in Serbia: New Empirical...

poreskih stopa (EGPS), uvodi pretpostavka da odluka pojedinca o utaji poreza ne zavisi od njegovog dohotka posle oporezivanja, već od njegovog raspoloživog dohotka. Rezultati pokazuju da elastičnost utaje poreza u odnosu na EGPS iznosi -0,3 - što je u skladu sa Jicakijevom teorijom utaje poreza, te da sklonost ka utaji opada sa rastom zarada, a da se povećava sa rastom dohotka od samostalne delatnosti. Rezultati takođe pokazuju da bi uvođenje prihodno neutralnog sistema progresivnog oporezivanja dohodaka od rada dovelo do rasta utaje poreza za 1 procentni poen.

Ključne reči: Utaja poreza, Poreska reforma, Dualni porez na dohodak građana, Efektivna granična poreska stopa

\section{Introduction}

Shadow economy alters market competitiveness, violates equity among equals and reduces the amount of government revenues. Shadow economy in Serbia of app. 31\% of GDP is among the highest in Central and Easter Europe (Krstić, et. al., 2013). Shadow economy is particularly large at the labour market. Further to Krstić and Sanfey (2011) in 2007 employment in informal economy in Serbia accounted for $34.9 \%$ of total number of (15-64) employees, while wages paid out in informal sector amounted to app. $26 \%$ of total wage bill (Krstić, et. al. 2013). Informal employment and labour taxes evasion are particularly large at the bottom of income distribution. It is argued that high labour taxes burden and its regressivity are some of the main drivers of large informal employment and high labour taxes evasion in Serbia (Arandarenko and Vukojević, 2008; Krstić and Sanfey, 2013).

According to Allingham and Sandmo's (A-S) seminal theoretical framework, tax evasion decision is regarded as portfolio choice, i.e. rational choice under uncertainty (Allingham \& Sandmo, 1972). The theory suggests that individual's tax evasion behaviour is dependent on the expected marginal benefits from tax evasion (the amount of evaded tax) and the expected costs of evasion (the fine to be paid multiplied by the probability of being detected). According to the theory (Allingham \& Sandmo, 1972; Sandmo, 2005), increase in fines or probability of being audited triggers decline in tax evasion, while the impact of change in the marginal tax rate (MTR) on tax evasion is ambiguous, being dependent on the scale of income and substitution effect. On the other hand, according to Yitzhaki's theorem, if tax is not imposed on the amount of hidden income, but rather on the amount of the evaded tax, there will be no substitution effect, implying that increase in MTR leads to decline in tax evasion (Yitzhaki, 1974). The relationship between tax evasion and MTR was subject to numerous empirical studies, mostly dealing with developed countries (USA, UK, Switzerland, etc.). The most of experimental studies (Webley et al. (1991; Gerxhani and Schram, 2006) suggest that higher 
Ranđelović S.: Tax Design-Tax Evasion Relationship in Serbia: New Empirical...

tax rates lead to lower compliance/higher evasion, which is also obtained in some observational studies (Clotfelter, 1983; Alm, 1992, Bernasconi and Zanardi, 2004). On the other hand, some studies argue that the negative relationship between the tax compliance and tax rates is a myth (Graetz and Wilde, 1985; Feinstein, 1991; Hindriks and Myles, 2013). To the best of our knowledge, the impact of design of tax-benefit system on labour taxes evasion decision in Central and Eastern European (CEE) countries was not extensively researched.

The underlying idea behind the A-S and Yitzhaki's model is that increase in MTR leads to decline in after-tax income, which then triggers taxpayers' behavioural response, in terms of non-reporting income. The most of empirical studies follow the same framework, treating tax evasion decision as a function of change in individual's after-tax income. However, change in income tax system may alter the amount of social security contributions, as well the eligibility of individual for (means- or income-tested) benefits or the amount of benefits to be received. Therefore, a change in disposable income ${ }^{2}$ may be different from the change in after-tax income. It may be argued that rational agent would make tax evasion decision based on the change in her/his disposable income, rather than on the change in after-tax income.

If high informal employment/labour taxes evasion is caused by high tax burden at the bottom of income distribution, the tax reform which would make income tax more progressive, is expected to reduce labour taxes evasion. The aim of this paper is to provide the evidence on the impact of the change in MTR and the degree of progressivity of income tax, on the scale of labour taxes evasion in Serbia, thus contributing to empirical literature on the relationship between income tax design and tax evasion in CEE countries. In estimating the impact of income tax reform on tax evasion, the interaction between income tax, social contributions and benefits is taken into account. This means that tax evasion decision will be treated as a function of the change in disposable income (captured by the effective marginal tax rate EMTR), rather than a function of the change in after tax income, which is novel approach compared to the other empirical studies on this topic. The evaluation is performed on 2007 Living Standard Measurement Survey data for Serbia, by combining tax-benefit microsimulation and econometric techniques.

Estimated elasticity of tax evasion rate to EMTR equals -0.3 , which supports Yitzhaki's theorem, since fine in Serbia is a function of evaded tax. The results suggest that switch to progressive income tax schemes in Serbia, which implies shift of the labour tax burden from the bottom to the upper levels of

\footnotetext{
${ }^{2}$ Disposable income equals gross (market) income minus income tax minus social contributions plus benefits.
} 
Ranđelović S.: Tax Design-Tax Evasion Relationship in Serbia: New Empirical...

income distribution, would not yield decline in the total labour taxes evasion. One explanation could be that lower tax wedge at the bottom of income distribution leads to increase in after-tax income, thus making some of the benefits recipients ineligible for benefits in the future, which drives them out (at least partially) to informal employment. In that case, it may be concluded that progressive income tax reform could yield decline in labour tax evasion in Serbia, if the eligibility for benefits becomes conditional on individual's gross income, rather than on net income.

The paper is organized in seven sections. In Section 2 theoretical framework for income tax evasion and overview of the empirical literature are presented. Section 3 deals with the size and properties of income tax evasion in Serbia. In Section 4 research motivation, data and methodology are described. In section 5 the empirical results are presented. Section 6 concludes.

\section{Determinants of tax evasion - theoretical framework and literature review}

Contemporary theory of tax evasion is based on the Allingham-Sandmo (A-S) model, which treats tax evasion as the problem of rationale choice under uncertainty (Allingham and Sandmo, 1972). A person who earns income W, will actually receive net income (after taxes) of $N=W(1-\theta)$, if the income tax at the rate of $\theta$ is imposed. That person may opt to report less than full amount of income, $X(X<W)$, in order to pay less taxes. If she/he is not audited by the authorities, her/his final net income would be $Y=W-\theta X$. Otherwise, if her/his file was audited by the Tax Authorities and the fine of $\pi$, on unreported income $(W-X)$ was assessed, then true net income would be $Z$ $=\mathrm{W}-\theta \mathrm{X}-\pi(\mathrm{W}-\mathrm{X})$. The A-S model assumes that individuals will act so as to maximize utility, which is the function of net income. In that case a taxpayer's utility would be $U(Y)$ or $U(Z)$ if she/he is audited or not, respectively.

Since a taxpayer does not know whether she/he will be audited or not, she/he will act in expected utility maximization manner. If the probability of being audited equals $p$, taxpayer's expected utility will be (Allingham \& Sandmo, 1972):

$E(U)=(1-p) U(W-\theta X)+P u(W-\Theta X-\pi(W-X))=(1-p) U(Y)+P u(Z)$

Equation (1) implies that a taxpayer will increase the non-reported income as long as her/his marginal increase in expected utility from one unit of evaded tax, exceeds the marginal loss of expected utility, due to imposition of penalty.

Increase in non-reported income may lead to rise in net income $(Y)$, if there is no tax audit, or to its decline (Z) in case of audit. Starting from the assumption 
Ranđelović S.: Tax Design-Tax Evasion Relationship in Serbia: New Empirical...

on decreasing marginal utility from non-reported income, it can be concluded that $\mathrm{MU}(\mathrm{Y})$ is falling, while $\mathrm{MU}(\mathrm{Z})$ is rising. In this context, a taxpayer will tend to increase the amount of non-reported income up to the point where his net increase in expected utility is the largest. This is achieved when the marginal increase in expected utility from tax evasion (if there is no tax audit) becomes equal to the marginal loss from expected utility (due to tax audit). This is called 'the optimal position' of a taxpayer (Yaniv, 2009):

$(1-p) \theta M U(Y)=p(\pi-\theta) M U(Z)$

Equations (1) and (2) imply that taxpayer's behaviour aimed at maximizing expected utility from tax evasion will depend on the income level, probability of detection of tax evasion, the penalty rate and MTR. ${ }^{3}$ According to the A-S model, when the true (actual) income varies, the ratio of reported-to-true income is rising, falling or remains steady, depending on weather a taxpayer's relative risk aversion is increasing, decreasing or constants function of income. The A-S model also implies that increase in probability of detection or the penalty rate leads to decline in tax evasion, while the impact of increase in the MTR on the amount of non-reported income is ambivalent - being dependent on the size of substitution effect and income effect. If the MTR increases, it becomes more expensive to report income, thus leading to its substitution by non-reported income, thus leading to decline in the optimal amount of reported income (the substitution effect). On the other hand, increase in the MTR, which reduces taxpayer's income if there is no audit $(Y)$, as well as his income in case of audit and detection of tax evasion (Z), would imply rise in respective marginal utilities $(M U(Y)$ and $M U(Z))$. Although $Y$ and $Z$ are falling by the same amount, relative changes in the marginal utility of income are not necessarily equal. If $\mathrm{R}$ is the relative change in the marginal utility of income ( $R=\Delta M U / M U)$, starting from the Arrow's theory of decreasing risk aversion, it can be concluded that the tendency to put some amount of money at risk is inversely related to the value of $R$ - if $Y>Z$, than $\mathrm{R}(\mathrm{Z})>\mathrm{R}(\mathrm{Y})$ (Yaniv, 2009). In that case the optimal amount of reported income would rise, which is the income effect. According to income effects, the rise in MTR reduces both $Y$ and $Z$, increasing taxpayer's relative risk aversion, which then triggers increase in the amount of reported income.

Implicit assumption of the A-S model is that the penalty for tax evasion is a function of non-reported income $(\pi(\mathrm{W}-\mathrm{X})$ )). Yitzhaki's critics (Yitzhaki, 1974) of the A-S model was based on the fact that in some countries, the fine is defined as the function of evaded tax $(\theta(\mathrm{W}-\mathrm{X}))$, rather than a function of

\footnotetext{
${ }^{3}$ Marginal tax rates could be found analytically by taking first differences of the relevant effective tax schedule, i.e. $M T R=d T(Y) / d Y$
} 
Ranđelović S.: Tax Design-Tax Evasion Relationship in Serbia: New Empirical...

hidden income. According to Yitzhak (1974), if fine is a function of evaded tax, the theoretical framework for tax evasion analysis would not encompass $\pi$, but rather the amount $\lambda \theta$, since the penalty is defined as certain percentage $(\lambda)$ of evaded tax $(\lambda \theta(\mathrm{W}-\mathrm{X}))$. If the condition for 'the optimal position' of the taxpayer is amended, so to replace $\pi$ with $\lambda \theta$, then, this condition takes the following form:

$$
\frac{(1-p) \theta}{p(\lambda \theta-\theta)}=\frac{(1-p) \theta}{p \theta(\lambda-1)}=\frac{(1-p)}{p(\lambda-1)}
$$

The equation (3) suggests that 'the optimal position' does not depend on MTR, since the relative price of reporting income is independent on the level of MTR. Now the increase in MTR leads to the rise in a price of reported as well as a price of non-reported income (by the same relative amount), which eliminates the substitution effect. Since the income effect still appears, the rise in MTR would trigger increase in the amount of reported income. This means that the rise in MTR would imply decline in tax evasion, if the penalty is set as a function of evaded tax.

Since the conclusions from the tax evasion theory on the impact of tax rates on the amount of tax evasion are ambivalent, and sometimes even counterintuitive, giving the final answer to the question on the nature and intensity of this relationship is matter of empirical analysis. Empirical studies unanimously show that higher probability of detection and penalty rates lead to more compliance/less tax evasion (Pommerehne and Weck-Hannemann, 1996; Keen et. al., 2008). Some studies claim that effect of higher audit rates on tax evasion is diminishing, with an estimated reported income-audit rate elasticity ranging from 0.1 to 0.2 (Witte and Woodbury, 1985). The empirical findings also suggest that the amount of non-reported income is positively related to the amount of true (actual) income, implying that high earners are more prone to evade taxes (Alm, 1992). With regard to the impact of MTRs on the amount of evaded tax, there is a consensus in empirical literature that relationship is significant, but not on the sign of the relationship. The majority of empirical studies on this topic show that higher MTR are associated with larger tax evasion. Empirical analyses for the USA show that the elasticity of reported income to the MTR is negative, ranging from -0.5 to -3.0 (Clotfelter, 1983; Alm, 1992), while studies for other developed countries find lower elasticities. The study for Switzerland indicates that the elasticity of nonreported income to MTR equals 0.076 (Pommerehne and Weck-Hannemann, 1996). Empirical literature also suggests that elasticity of reported income to MTR depends on the way income is obtained. Boylan and Sprinkle (2001) find that when income is endowed, participants respond to a MTR increase by reporting less taxable income, while in case income is earned participants respond to a MTR increase by reporting more taxable income. On the other 
Ranđelović S.: Tax Design-Tax Evasion Relationship in Serbia: New Empirical...

hand, some studies find a positive relation between MTR and reported income (Feinstein, 1991).

\section{Size and properties of income tax evasion in Serbia}

Further to recent studies (Krstić et. al., 2013), shadow economy in Serbia is estimated at $31.4 \%$ of GDP, being by $1 / 6$ higher than CEE average (the higher shadow economy is found only in Bulgaria, while all other CEE countries face lower shadow economy). Informal work accounts for a large share of shadow economy - the rate of informality in terms of incomes is higher than in consumption.

Table 1. Basic indicators of tax evasion in Serbia

\begin{tabular}{lccc}
\hline $\begin{array}{l}\text { Type of labor } \\
\text { income }\end{array}$ & $\begin{array}{c}\text { Structure of } \\
\text { labor income }\end{array}$ & $\begin{array}{c}\text { Share of non-reported } \\
\text { in true income }\end{array}$ & $\begin{array}{c}\text { Share of taxpayers who } \\
\text { underreport income }\end{array}$ \\
\hline Wages & $75 \%$ & $8.9 \%$ & $16.6 \%$ \\
$\begin{array}{l}\text { Self-employment } \\
\text { income }\end{array}$ & $25 \%$ & $43.9 \%$ & $64.4 \%$ \\
\hline Total & $100 \%$ & $21.2 \%$ & $25.6 \%$ \\
\hline
\end{tabular}

Source: Author's calculation

According to the 2007 Living Standard Measurement Survey (see Table 1), which contains the rata on individuals' reported and actual income, the share of non-reported to true (actual) total labour income is close to $21 \% .{ }^{4}$ The same survey shows that $25.6 \%$ of working taxpayers tend to underreport their incomes. The later studies show that after the crisis the tax evasion rate has increased to over $27 \%$ in 2010-2012 (Krstić, et. al., 2013).

The data also show that informal work and tax evasion are considerably (five times) higher for a self-employed than for an employed individual. Around $1 / 2$ of all wages in Serbia are paid out by public sector, where tax evasion is close to zero. If wages paid out by public sector are fully reported, the wage tax evasion rate (ratio of non-reported to true income) in private sector is close to 18 percent. Large difference in tax evasion rates between wage tax and selfemployment income tax may arise due different tax collection mechanism (wage tax is withheld by employer, at source, while self-employment income tax is assessed by the Tax Authorities and paid by individuals).

\footnotetext{
${ }^{4}$ Since in Serbia income tax rate is flat, the rate of tax evasion equals the rate of income nonreporting. 
Ranđelović S.: Tax Design-Tax Evasion Relationship in Serbia: New Empirical...

The LSMS 2007 data show that more than 50\% of total non-reported employment income and more than $65 \%$ of total non-reported selfemployment income belongs to individuals from top three deciles (see Table 2). However, the same survey data suggest that the distribution of propensity to evade differs between wage earners and self-employed individuals. Propensity to evade (measured by the ratio of reported and true income) is decreasing in the level of wage, while with self-employed taxpayers it is close to U-shaped (Figure 1).

Table 2. Distribution of true and non-reported income per deciles (\%)

\begin{tabular}{|c|c|c|c|c|}
\hline \multirow[b]{2}{*}{ Decile } & \multicolumn{2}{|c|}{ Wages } & \multicolumn{2}{|c|}{ Self-employment } \\
\hline & True & $\begin{array}{c}\text { non- } \\
\text { reported }\end{array}$ & True & $\begin{array}{c}\text { non- } \\
\text { reported }\end{array}$ \\
\hline 1 & 0.4 & 1.0 & 1.6 & 0.4 \\
\hline 2 & 2.5 & 4.0 & 4.2 & 2.5 \\
\hline 3 & 4.4 & 5.7 & 4.0 & 2.5 \\
\hline 4 & 6.1 & 7.0 & 5.5 & 3.4 \\
\hline 5 & 7.9 & 8.0 & 5.9 & 5.7 \\
\hline 6 & 10.0 & 10.9 & 7.5 & 6.8 \\
\hline 7 & 11.8 & 13.6 & 10.2 & 10.8 \\
\hline 8 & 14.7 & 16.1 & 12.1 & 13.7 \\
\hline 9 & 17.5 & 12.6 & 14.3 & 14.3 \\
\hline 10 & 24.7 & 21.1 & 34.7 & 39.9 \\
\hline
\end{tabular}

Source: Author's calculation based on LSMS 2007

Figure 1. Tax evasion rate per deciles

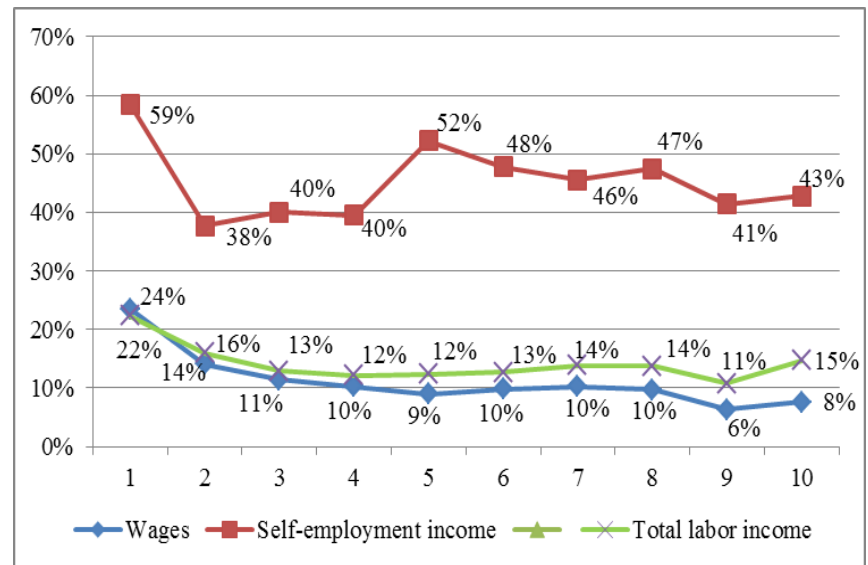

Source: Author's calculation based on LSMS 2007 
Ranđelović S.: Tax Design-Tax Evasion Relationship in Serbia: New Empirical...

High tax evasion rate at low-wage levels may be explained by high unemployment rate of low-skilled population, which is why the decision on formal or informal employment is often made by employer, rather than by employee. In addition, high informality is explained by the high tax wedge, particularly at the bottom of income distribution (Koettl, 2010; Arandarenko and Vukojević, 2008).

\section{Research motivation, methodology and data}

Impact of MTR and income tax scheme on informal employment and tax evasion was subject to many empirical studies, the most of them dealing with developed (EU and OECD) countries (for review of empirical literature see Schneider and Enste, 2000). However, to the best of our knowledge, this topic was not separately and extensively researched in transition economies, although it is particularly important for CEE economies since they are facing considerably higher shadow economy/informal employment compared to developed countries.

Empirical studies on the relationship between income tax scheme and the tax evasion are usually based on the A-S model assumption which says that tax evasion is affected by the change MTR, since change in MTR alters taxpayer's after-tax income. However, that approach does not account for the interaction between income tax, social contributions system and benefits scheme. Increase in the MTR is expected to reduce taxpayer's after-tax income. That could make her/him eligible to some means- or income-tested benefits program (e.g. cash social assistance, child allowance, etc.), to which she/he was not entitled before. This means that increase in the MTR could cause rise in his disposable income, if the new benefit is larger than the marginal increase in the tax burden. Besides that, depending on the tax incidence, the change in the MTR could alter the base for calculation of social security contributions, which also may affect the amount of individual's disposable income. Therefore, it is reasonable to assume that rational individual would make the economic decision (to evade or not) based on the change in his final disposable income, rather than on the change in after-tax income. That novel approach is exploited in this paper, in order to make the model and analysis closer to reality.

In order to capture the interraction between taxes, contributions and benefits and calculate the total impact of change in MTR on the disposable income, the Effective Marginal Tax Rates (EMTR) are used. EMTR indicates the effective rate at which one additional unit of income has been taxed away, when income tax, social contributions and benefits are taken into account. The effective tax burden is calculated as the difference between the marginal 
Ranđelović S.: Tax Design-Tax Evasion Relationship in Serbia: New Empirical...

increase in taxes/contributions and the marginal increase in the amount of benefits the taxpayer becomes entitled to (Immervoll, 2004). Therefore, EMTR captures the effective change in disposable income, resulting from the interaction between income tax, social contributions and benefits.

To calculate EMTR for the working population in this paper the following formula is used: ${ }^{5}$

$$
\operatorname{EMTR}_{i}=1-\frac{D Y_{j}}{d_{i}}
$$

where $d_{i}$ is the income increment for individual $i$, while $D Y_{j}$ is disposable income of household $j$ to which this individual belongs.

For each individual in the household, these labour incomes (wages and selfemployment income) are increased by 3 percent, and then tax-benefit microsimulation model for Serbia (SRMOD) is used to re-compute income tax, social contributions and benefits (on LSMS 2007 dataset) and to compare the results with the baseline situation. Based on the results and equation (4), EMTRs are calculated for each taxpayer. ${ }^{6}$

For the purpose of this analysis, SRMOD is used to compute EMTRs for each taxpayer under existing tax-benefit scheme in Serbia, as well under the hypothetical income tax reform system, which implies introduction of progressive taxation of labour income.

SRMOD is also used to compute tax evasion rates for each taxpayer under existing tax-benefit scheme. Standard OLS method is used to estimate elasticity of tax evasion rate to EMTR. Based on the calculated changes in EMTR's due to tax reform and estimated elasticity of tax evasion rate to EMTR, impact of tax reform on tax evasion rate is estimated.

The analysis is conducted on the LSMS 2007 dataset, encompassing a representative sample of 5,557 households (encompassing 17,335 individuals). The survey is conducted by the Statistical Office of Serbia in May/June 2007, based on World Bank methodology. This dataset has been chosen because it includes detailed information on incomes from various sources, the data on the amounts of taxes paid as well as on the amounts of social benefits claimed.

The baseline scenario in this research reflects 2007 tax-benefit policies included in SRMOD, since the dataset relates to that year. According to 2007

\footnotetext{
${ }^{5}$ For further details on methodology of calculation of EMTR see Immervoll (2004)

${ }^{6}$ SRMOD is tax-benefit microsimulation model for Serbia, developed on EUORMOD platform. For more details on SRMOD see Randjelovic and Zarkovic-Rakic (2013) 
Ranđelović S.: Tax Design-Tax Evasion Relationship in Serbia: New Empirical..

income tax scheme, incomes from different sources are taxed at different tax rates (see Table 3).

Table 3. Income tax system in Serbia in 2007

\begin{tabular}{lccc}
\hline Source of income & $\begin{array}{c}\text { Statutory } \\
\text { tax rate }\end{array}$ & Deductions & Effective tax rates \\
\hline Self-employment & $10 \%$ & - & $10 \%$ \\
Salary/wage & $12 \%$ & RSD 5,050 & $10,35 \%$ \\
$\begin{array}{l}\text { Agriculture and forestry } \\
\text { Authorship rights, related } \\
\text { rights and intellectual }\end{array}$ & $14 \%$ & - & $14 \%$ \\
property rights & $20 \%$ & $34 \%, 43 \%, 50 \%$ & $10 \%, 11,4 \%, 13,2 \%$ \\
$\begin{array}{l}\text { Capital } \\
\text { Immovable property }\end{array}$ & $20 \%$ & $100 \%, 20 \%, 0 \%$ & $0 \%, 16 \%, 20 \%$ \\
$\begin{array}{l}\text { Capital gains } \\
\text { Other income }\end{array}$ & $20 \%$ & $20 \%$ & $16 \%$ \\
\hline
\end{tabular}

Source: Personal Income Tax Law

In order to evaluate the effects of changes to MTR/income tax scheme on tax evasion rate, hypothetical - revenue neutral, income tax reform scenario is developed. Under reform scenario, Nordic-style, dual income tax scheme is introduced, implying progressive taxation of labour income and flat tax on capital incomes. Under reform scenario wages, $80 \%$ of self-employment income and income from agriculture and forestry are included in labour income, while interest, dividends, capital gains, rental income and $20 \%$ of selfemployment income are included in capital income. Total labour income may be reduced by the standard deduction of RSD 9,000 per month (app. 24\% of average gross wage). Taxable labour income may also be reduced by itemized deductions for dependent children, education and healthcare expenditures (ceiling for education and healthcare expenditures deductions equals RSD 4,000 , i.e. $10.5 \%$ of average gross wage per month). Final taxable labour income is taxed at the rates of $10 \%$ (up to RSD 10,000), $15 \%$ (from RSD 10,000 do RSD 25,000) and 20\% (above RSD 25,000). Capital income is taxed at the flat rate of $10 \%$.

\section{Empirical results}

The results show that under 2007 income tax scheme weighted average EMTR equals 15.4 percent (see Table 4), suggesting that each additional unit 
Ranđelović S.: Tax Design-Tax Evasion Relationship in Serbia: New Empirical...

of income is effectively taxed away at the rate of $15.4 \%$, when income tax, social contributions and change in benefits are taken into account. The results also show that under dual income tax scheme EMTR would decline by 2.4 percentage points (app. 15.6 percent) compared to the baseline scenario. Fall in EMTR is not equal across entire population, but rather large at the bottom of income distribution and continuously declining at higher income levels (see Figure 2). Larger decline in EMTR at lower income levels compared to higher income levels is due to higher progressivity of dual income tax compared to current income tax scheme. The results of microsimulation analyses show that progressivity measured by Kakwani index is increasing from 0.119 (under current income tax scheme) to 0.212 (under dual income tax). This results is in line with other studies showing that switch to dual income tax scheme would increase progressivity and reduce inequality in income distribution in Serbia (see Randjelovic and Zarkovic-Rakic, 2011).

In order to calculate the effects of tax reform on tax evasion, it is necessary to estimate the relationship between the EMTR and tax evasion rate. Econometric model specification relies on the A-S model, modified in the part related to MTR/EMTR. Dependent variable in this model is the tax evasion rate (TAR), defined as the share of non-reported income in the total actual income. Explanatory variables are the total labour income and EMTR. Since the tax evasion rate in Serbia significantly differs between employment and self-employment income, the total labour income is split into taxpayer's true (total) employment income (WAG) and taxpayer's true (total) self-employment income (SEI). We have also tried to include marginal costs of tax evasion (the probability of detection and fines) into the model. The variable on the probability of detection and fines have been constructed, based on the Tax Authorities data, but the estimated coefficients were not statistically significant. The data show that probability of detection in Serbia is rather small compared to other European countries (due to insufficient number of tax inspectors and inappropriate risk management scheme). Consequently, taxpayers perceive probability of detection (and marginal costs of tax evasion) rather small (close to zero), which is confirmed by survey data (Krstić et. al., 2013).

Table 4. EMTRs under different income tax schemes

\begin{tabular}{lcc}
\hline & Current & Dual PIT \\
\hline Weighted average EMTR (\%) & 15.4 & 13.0 \\
$\Delta$ EMTR $(\mathrm{pp})$ & - & -2.4 \\
$\Delta$ EMTR $(\%)$ & - & -15.6 \\
\hline
\end{tabular}

Source: Author's calculation 
Ranđelović S.: Tax Design-Tax Evasion Relationship in Serbia: New Empirical...

Figure 2. EMTRs per deciles under different income tax schemes

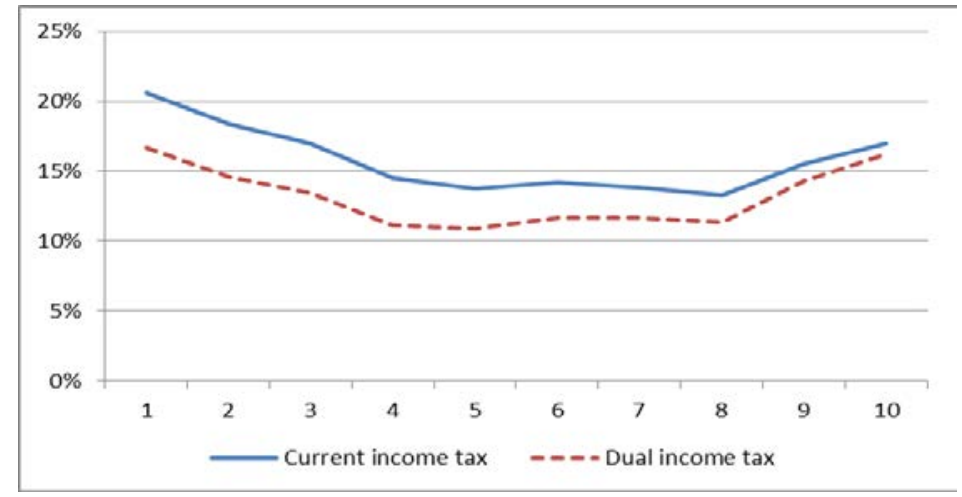

Source: Author's calculation

Therefore, the relationship between tax evasion rate and EMTR is estimated by means of the following model:

$$
\log T A R=\beta_{0}+\beta_{1} \log W A G+\beta_{3} S E I+\beta_{4} \log E M T R+\varepsilon_{i}
$$

By means of standard regression analysis procedure $(\alpha=0.05)$, using OLS estimation method, the following estimates have been obtained:

Table 5. OLS estimation method

\begin{tabular}{lccr}
\hline Dependent variable & \multicolumn{3}{c}{ Independent variables } \\
\hline log TAR & logWAG & logSEI & logEMTR \\
\hline Estimate & $-0.63^{\star \star \star}$ & $0.49^{\star \star \star}$ & $-0.30^{\star}$ \\
\hline t-statistics & -9.30 & 4.67 & -1.85 \\
Probability (p) & 0.000 & 0.000 & 0.068 \\
\hline $\begin{array}{l}\text { Other statistical } \\
\text { properties }\end{array}$ & $\mathrm{R}^{2}=0.82 ;$ & $\mathrm{F}=251.15(\mathrm{p}=0.000) ; \mathrm{DW}=1.98 ; \mathrm{JB}=0.7795$ \\
\hline
\end{tabular}

Source: Author's calculation

This econometric model has good statistical properties. Regression coefficients are statistically significant both individually and jointly, while no multicolinearity has been identified (goodness of fit of auxiliary regressions does not exceed 0.25). ${ }^{7}$ Problem of heteroskedasticity has been resolved.

\footnotetext{
${ }^{7}$ Regression coefficient with the EMTR variable is statistically significant at $10 \%$ level of significance.
} 
Ranđelović S.: Tax Design-Tax Evasion Relationship in Serbia: New Empirical...

The model has satisfactory goodness of fit of 0.82 . The model has passed the standard tests of model specification (Ramsey's test and Jarque-Berra test of normality of residuals).

The results suggest that the relationship between the EMTR and tax evasion rate is negative, the elasticity being relatively small $(-0.30)$, which means that in Serbia substitution effect prevails over income effect. This result is in line with the Yitzhaki's argument (Yitzhaki, 1974), since in Serbia fine is defined as a function of evaded tax, rather than a function of hidden income. In order to investigate the cause of such results, two auxiliary regressions with the same regressors have been run - one for the population earning income higher than average, and the other for population earning less than average. The results indicate that the negative elasticity of tax evasion rate to EMTR for higher earners is larger than for low income earners (at the very bottom of income distribution, this elasticity becomes positive). This may be the case because top income earners can replace their labour income by capital income (dividends), while low earners tend to switch to informal sector if EMTR is increased. The results also show that propensity to evade is declining as employment income is rising, which is in line with conclusions based on Figure 1. This means that low-wage earners are more prone to evade than higher wage earners. This is due to high unemployment rate of low-skilled individual, which makes them inelastic to employer's decision on informality of work arrangement. On the other hand positive elasticity of TAR to SEI implies that individuals at higher levels of self-employment income (lawyers, doctors, accountants, etc.) are more prone to evade than low-skilled self-employed individuals (mechanics, etc.).

Table 5. Effects of income tax reform on the amount of income tax evasion

\begin{tabular}{lc}
\hline & Dual income tax \\
\hline$\Delta$ EMTR (\%) & -15.6 \\
Elasticity of TAR to EMTR & -0.30 \\
$\Delta$ Tax evasion rate (\%) & 4.7 \\
\hline Tax evasion rate after the reform (\%) & 22.2 \\
\hline
\end{tabular}

Source: Author's calculation

The results based on the change in EMTR due to tax reform and estimated elasticity of tax evasion rate to EMTR indicate that introduction of dual income tax in Serbia would increase tax evasion rate by one percentage point - from 21.2 to 22.2 percent (Table 5). Hypothetical dual income tax model differs from current income tax scheme by the degree of progressivity in taxation of labour income. Progressive taxes are expected to reduce total tax evasion, when tax evasion is high at the bottom of income distribution, since they shift 
Ranđelović S.: Tax Design-Tax Evasion Relationship in Serbia: New Empirical...

part of the tax burden from low to higher income levels. However, when lower taxes lead to higher after-tax income, making individual ineligible for benefits, the effects of tax reform on reduction of tax evasion may be missing.

\section{Concluding remarks}

Informal work accounts for the large share of the total shadow economy in Serbia. Shadow economy, informal work and labour taxes evasion are considerably higher in CEE countries and Serbia compared to developed countries of Western Europe and North America, which makes the discussion on policy measures aimed at reducing tax evasion particularly important for CEE countries.

Economic theory and empirical literature for developed countries argue that income tax evasion may be tackled through increase in fines and probability of detection. Standard theoretical (A-S) model is silent with regards to the sign of impact of MTR on tax evasion, while empirical literature for developed countries mostly suggests that this relationship is positive. However, some theoretical models (e.g. Yitzhaki's) claim that this relationship may be negative, if fine for tax evasion is a function of evaded tax, rather than a function of hidden income.

In this paper we have provided empirical evidence on the impact of change in income tax scheme on tax evasion in Serbia, thus contributing to empirical literature on this topic for transition economies. Opposite to standard empirical approach, which investigates the relationship between MTR and tax evasion, we take into account the interaction between income tax, social contributions and benefits, thus making tax evasion decision a function of disposable income, rather than a function of after-tax income. Such approach is aimed at making empirical model more close to reality.

The results suggest that the relationship between EMTR and tax evasion in Serbia is negative, which is in accordance with Yitzhaki's theory, since fines in Serbia are defined as a function of evaded tax. Our results also suggest that tax reform, which would imply introduction of progressive taxation of labour income, would yield adverse effects on the tax evasion. Although switch to progressive taxation of labour income lifts some of the tax burden for lowincome earners, it also makes some of them ineligible to benefits, which may drive them to work (at least partly) in informal sector. Therefore, redistribution of tax burden (from low to high income earners) could contribute to fight against tax evasion, if such reform is accompanied with the reform of benefits system. Under such reform eligibility criteria (for benefits) would be attached to gross, rather than net income, although it might make means- or incometested benefits less targeted. 
Ranđelović S.: Tax Design-Tax Evasion Relationship in Serbia: New Empirical...

\section{References}

Allingham, G., \& Sandmo, A. (1972) Income tax Evasion: a theoretical analysis. Journal of Public Economics, (1). 323-338.

Alm, J., Jackson, B., \& McKee, M. (1992). Estimating the determinants of taxpayer compliance with experimental data. National Tax Journal, 45(1). 107-114.

Arandarenko, M., \& Vukojevic, V. (2008). Labor costs and labor taxes in the Western Balkans. Mimeo. Washington, DC: World Bank

Bernasconi, M., \& Zanardi, A. (2004). Tax evasion, tax rates and reference dependence. FinanzArchiv, 60(4), 422-445.

Boylan, S., \& Sprinkle, G. (2001). Experimental evidence on the relation between tax rates and compliance: the effect of earned vs. endowed income. The Journal of the American Taxation Association, 23(1), 75-90.

Clotfelter, C. (1983). Tax evasion and tax rates: an analysis of individual returns. The Review of Economics and Statistics, 65(3), 363-373.

Feinstein. J. S. (1991). An econometric analysis of income tax evasion and its deteclion. RAND Journal of Economics, 22, 14-35.

Gerxhani, K., \& Schram, A. (2006). Tax evasion and income source: a comparative experimental study. Journal of Economic Psychology, 27(3), 402-422.

Graetz, M., \& Wilde, L. (1985). The Economics of Tax Compliance: Fact and Fantasy. National Tax Journal (September), 345-363.

Hyndriks, J. \& Myles, G. (2013). Intermediate Public Economics. MIT Press, Cambridge

Immervoll, H. (2004). Average and marginal effective tax rates facing workers in the EU. A micro-level analysis of levels, distributions and driving factors. OECD Working Paper No. 4/2004, OECD, Paris

Keen, M., Yitae, K., \& Varsano, R. (2008). The flat tax(es), principles and evidence. International Tax and Public Finance, (15), 712-751.

Krstić, G., \& Sanfey, P. (2011). Earnings inequality and informal economy: evidence from Serbia. Economics of Transition, 19(1), 179-199.

Krstić, G., Schneider, F., Arsić, M., Arandarenko, M., Radulović, B., Ranđelović, S., \& Janković, I. (2013). Shadow economy in Serbia: new findings and recommendations for reform. USAID and FREN Study (available at:

http://www.fren.org.rs/sites/default/files/articles/attachments/the-shadow-economy-inserbia-study.pdf)

Koettl, J. (2010, December). Do formal jobs pay in the Western Balkans? The role of labour taxes and social benefits in creating formal jobs. The paper presented at the World Bank's conference Poverty and Inclusion in Western Balkans, Brussels.

Pommerehne, W., \& Weck-Hannemann, H. (1996). Tax rates, tax administration and income tax evasion in Switzerland. Public Choice, 88: 161-170.

Randjelovic, S., \& Zarkovic-Rakic, J. (2011). Addressing inequality and poverty with tax instruments. Economic Annals, 54(19), 7-26.

Randjelovic, S., \& Zarkovic-Rakic, J. (2013). Improving working incentives: evaluation of tax policy reform using SRMOD. International Journal of Microsimulation, 6(1), 157-176.

Sandmo, A. (2005). The theory of tax evasion: a retrospective view. National Tax Journal, Vol. LVII(4), 643-663.

Schneider, F., \& Enste, D. (2000). Shadow economies: size, causes and 
Ranđelović S.: Tax Design-Tax Evasion Relationship in Serbia: New Empirical...

consequences. Journal of Economic Literature, XXXVIII: 77-114.

Yaniv, G. (2009). The tax compliance demand Curve: a diagramatical Approach to income tax evasion. Journal of Economic Education, 40(2), 213-224.

Yitzhaki, S. (1974). A note on income tax evasion: a theoretical analysis. Journal of Public Economics, (3), 201-202.

Witte, A. D., \& Woodbury, D. F. (1985). The effect of tax laws and tax administration on tax compliance. National Tax Journal, 38(1). 1-13. 